\title{
Does Having a Living Child Increase Women's Risk of Intimate Partner Violence? Evidence from 2008- 2013 Nigeria Demographic and Health Surveys
}

\author{
Bola Lukman Solanke, Senior Lecturer, PhD \\ Department of Demography and Social Statistics, \\ Obafemi Awolowo University, Nigeria \\ Femi Monday Ilevbare, Lecturer I, PhD \\ Department of Psychology, \\ Obafemi Awolowo University, Ile-Ife, Nigeria
}

doi: 10.19044/esj.2017.v13n11p201 URL:http://dx.doi.org/10.19044/esj.2017.v13n11p201

\begin{abstract}
This study examined the relationship between number of living children and intimate partner violence. This was with the view to ascertaining whether having living children or not having a living child was associated with increased risk of intimate partner violence among currently married women in Nigeria. The study analyzed data from 2008-2013 Nigeria Demographic and Health Surveys. The binary logistic regression was applied. Results showed that women who had two or more living children were $20.5 \%$ more likely to experience intimate partner violence compared with women who had no living child (OR=1.205; CI: 0.993-1.461). The study concluded that having living children increase women's risk of intimate partner violence in Nigeria. Women experiencing intimate partner violence should seek psychosocial counselling to reduce the incidence of intimate partner violence that may arise from childbearing.
\end{abstract}

Keywords: Intimate partner violence, living child, childless, women, children, Nigeria

\section{Introduction}

In Nigeria, and other parts of sub-Saharan Africa, fertility though declining, remain at high levels. Across the world, all the twelve countries with highest total fertility rates are in sub-Saharan Africa, with no subSaharan African country in the league of the ten countries with lowest total fertility rates in the world (Population Reference Bureau [PRB], 2015). One of the reasons why fertility has remained high in sub-Saharan Africa is the socio-cultural demand for large family size. The influence of family and 
community on couples's family size decisions described in earlier research (Caldwell \& Caldwell, 1987; Fapounda \& Todaro, 1988), persists in many parts of sub-Saharan Africa, in spite of changing socio-economic structures, and implementation of national family planning programs (Cleland, Ndugwa \& Zulu, 2011). In sub-Saharan African countries where fertility transitions have been observed, stall within the transitions have also been observed (Ezeh, Mberu \& Emina, 2009).

Fertility, thus, remain an important component of African social structures, particularly, the marriage system. In virtually all Nigerian communities, childbearing is the main goal of marriage, and contributes to marital satisfaction (Onyishi et al., 2012). Apart from providing old age security to parents, children also have some economic roles, such as working on family farms or assisting in family business. In many urban areas of Nigeria, child labour, such as street hawking, though improper and illegal in some cities, is widely perceived as part of economic contributions of children to family income and survival (Omokhodion \& Uchendu, 2010). Unlike in more developed countries of Europe and North America, voluntary or involuntary childlessness is widely resented and not yet accepted as a reproductive behavior in Nigeria (Ibisomi \& Mudege, 2014). Most married women in Nigerian communities also do not believe that their marriages are secured without producing children. Some do patronise 'baby factories' to exchange money for a child in order to become more socially relevant in the community (Makinde et al., 2015). Many who had to remarry either due to lost of a partner or marriage dissolution, often have to bear more children regardless of previous number of children, in order to secure their new union.

Research evidence confirms that marital unions experiencing inability to produce children often ends in dissolution (Kalmijn \& Poortman, 2006; Sultan, 2010). Nevertheless, many women suffer involuntary childlessness in sub-Saharan Africa (Larsen et al., 2010; Hammarberg \& Kirkman, 2013; Inhorn \& Patrizio, 2015), with little or no access to assisted reproductive technologies (Inhorn, 2009; Ola, 2012). Such childlessness may result either from inability to have a live birth after years of being sexually active, and not using contraceptives (Larsen, 2005). It may also result from experiencing child mortality (Boerma \& Mgalla, 1999). More often than not in Nigeria and other sub-Saharan African countries, married women who are yet to have a living child are pressurised to have one, stigmatised, and experienced several types of marital discord, such as mental stress, sexual dysfunction, isolation or exclusion, and intimate partner violence (Ofovwe \& Agbontaen-Eghafona, 2009; Fledderjohan, 2012).

Intimate Partner Violence (IPV) is the most disturbing of the marital discord experienced by women who are yet to have a living child, because it not only endangers women's sexual and reproductive health like other 
consequences of marital discord, it may also lead to permanent disability (that further hinder ability to have a live birth) or death. Intimate partner violence refers to any behaviour by a current or former partner in a marital union or intimate relationships that causes physical, psychological or sexual harm to any of the partner in the union or relationship (United Nations [UN], 2012; World Health Organization [WHO], 2013). IPV is not only widespread across the world, it has become a major public health issue (Head et al., 2014), leading to non-fatal and fatal outcomes among women, who are the main victims of IPV (Devries et al., 2011; Jina \& Thomas, 2013; Pereira, Vieira \& Magalhaes, 2013). Though, IPV has also been reported against pregnant or parous women (Devries et al., 2010; Bessa et al., 2014), but intimate partner violence against women who are yet to have a living child deserve more attention in Africa, because it aggravates the psycho-social problem of women who are already in a socially and economically disadvantaged situation. Such women may need both bio psychosocial and professional medical expertise to overcome the situation (Van den Broeck et al., 2010).

Studies in Nigeria and elsewhere have associated not having a living child with intimate partner violence. While fewer of these studies analyzed both childless and parous women (e.g. McCloskey et al., 2005; Koenig et al., 2006; Uwaoma, Osita-Njoku \& Madukwe, 2012), most of these studies focused solely on infertile women (Ardabily et al., 2011; Aduloju et al., 2015; Iliyasu et al., 2016; Ozgoli et al., 2016; Yildizhan et al., 2016). This creates a knowledge gap for three reasons. One, it is not all women who have no living child that are infertile. Some may have had at least a child in the past, but may have experienced child mortality. Two, childlessness is best measured in relation to women who have reached the end of their reproductive life span, because some who are presently childless may still have a child before the end of their reproductive age. It is thus, preferable to examine number of living children among women who are still within the reproductive life span. Three, all women who have been married for reasonable length of time, but involuntarily without a living child, may be exposed to marital discord, including partner violence, and not just infertile women. Clear understanding of the association between number of living children and partner violence, thus, require assessment of the risks of intimate partner violence among women who had at least a living child, and women who had no living child. This study attempts to fill this knowledge gap by raising the research question: does having or not having a living child increase women's risk of intimate partner violence?

The objective of the study was to examine the relationship between number of living children and intimate partner violence. This was with the view to ascertaining whether having living children or not having a living 
child was associated with increased risk of intimate partner violence among currently married women in Nigeria. The study improves understanding of the underlying causes of intimate partner violence by providing empiricalbased information on a likely cause of intimate partner violence in the country. In addition, it is important to explicitly examined association between number of living children and intimate partner violence in Nigeria because there is little public health support for women experiencing lack of a living child in Nigeria, as existing intervention is beyond the reach of most childless women (Federal Ministry of Health [FMoH], 2010).

\section{Materials and Methods:}

\section{Context}

The study was conducted in Nigeria, the seventh most populous country in the world, and most populous country on the African continent (PRB, 2015). Fertility is high in Nigeria, particularly, in Northern Nigeria. However, based on estimates from the 2013 Nigeria Demographic and Health Survey (NDHS), fertility is gradually declining in the country with a total fertility rate of 5.5 per woman as at 2013, compared with 5.7 per woman in 2003 and 2008. Among currently married women in Nigeria, the mean number of children ever born is 4.0 in 2013, with mean number of living children of 3.32, indicating that some of the women have been affected by child mortality. Voluntary childlessness is very rare in Nigeria. In 2013, only 3\% of all women had not borne at least a child, but $8.9 \%$ of currently married women had no living child. Current estimates of intimate partner violence in the country show that $25 \%$ of ever-married women had ever experienced at least one type of partner physical, sexual, or emotional violence, with 19\% of them experiencing partner violence in the last 12 months preceding the 2013 NDHS. The NDHS further revealed that among all women of reproductive age, women who had no living child had experienced more partner physical violence since age 15 years, compared with women who had children (National Population Commission [NPC] \& ICF International, 2014).

The prevalence of intimate partner violence and other gender-based violence is expected to reduce by the enforcement of a recent legislation (Violence Against Persons [Prohibition] Act of 2015), that criminalises major forms of gender-based violence in the country (Onyemelukwe, 2016). Nonetheless, a number of population, gender and health policies and programmes are being implemented in the country to reduce extent of partner violence, and improve women's sexual and reproductive health. These include National Policy on Population for Sustainable Development (NPC, 2004), Revised National Health Policy (FMoH, 2004), and National Gender Policy (Federal Ministry of Women's Affairs and Social 
Development [FMWA \& SD], 2006). Though, the population and health policies targets providing essential services to address fertility challenges of childless individuals and couples, medical counselling is the key formal assistance that is widely accessible to women and couples who had fertility problems, because assisted reproductive techniques are too expensive for majority of people who need them $(\mathrm{FMoH}, 2010)$. In the absence of medical assistance, individual and couples have access to child adoption in the country, but general attitude to child adoption is still poor in Nigeria (Omosun \& Kofoworola, 2011).

\section{Data and Sample}

The study analysed data from 2008 and 2013 NDHS. The reason for combining the two surveys was the small proportions of currently married women who had no living child in each round of the surveys. The surveys were conducted using the survey methodology designed for the Demographic and Health Survey (DHS) program in developing countries. Essentially, the methodology involves sampling through a two-staged process of randomly selecting clusters first, and thereafter randomly selecting households (ICF International 2012). Both the 2008 and 2013 NDHS were implemented by the National Population Commission. Detail designs of the surveys have been published (NPC \& ICF International, 2009; NPC \& ICF International, 2014). Some of the women covered in the surveys were excluded from the current study. The inclusion criteria used was having been included in the domestic violence module, being currently married, not currently pregnant, and being aged 25-49 years. This age group was focused to ensure that most of the women had been married for reasonable length of time, based on current national median age of first marriage of 18.1 years (NPC \& ICF International, 2014). The weighted sample size was 24,066 women.

\section{Dependent variable}

The dependent variable was intimate partner violence. The three types of intimate partner violence measured in the NDHS were physical, sexual, and emotional violence. The information was collected by asking women to provide a 'yes' or 'no' response to each measure of specific partner violence. With respect to partner physical violence, women were asked if their current or former male partner had ever pushed, shook, or threw something at them; slapped; twisted their arm or pulled their hair; punched them with fist or with something else; kicked, dragged, or beat them up; tried to choke or burn them; threatened or attacked them with a knife, gun, or any other weapon with the aim of hurting them. With respect to partner sexual violence, women were asked whether their male partner had 
ever physically forced them to have unwanted sex or physically forced them to perform other unwanted sexual acts. In respect of partner emotional violence, women were asked to affirm whether their male partner ever said or did something to humiliate them in the presence of others; threatened to hurt or harm them or someone close to them; or insult them or make them feel bad about themselves (NPC \& ICF International, 2014). Measures of each type of violence were combined to form two categories of 'ever' or 'never' experienced physical, sexual, and emotional violence. A single variable showing women who had ever or never experienced at least one type of partner violence was then derived by combining the three types of partner violence. Women who experienced at least one type of partner violence were grouped as 'ever' experienced, with code '1', while women who had never experienced any partner violence were grouped as 'never' experienced, with code ' 0 '. The outcome of interest in the study was ever experienced at least one type of partner violence.

\section{Independent variables}

The main independent variable was number of living children. The variable was re-coded into three categories. The first category was 'no living child'. This group of women are not necessarily infertile. They refer only to currently married women who were yet to have a living child as at the time of the survey. The second category was 'one living child', while the third category was ‘two or more living children'. Other variables are included in the study to assess changes in partner violence as other variables in the social environment are added to the analyses. The other independent variables analyzed are six women's individual characteristics, and six household characteristics. The individual characteristics are education, age, age at first marriage, interparental violence, attitude to wife-battery, and pregnancy termination. All these variables have been associated with partner violence in previous studies on domestic violence (Stephenson et al., 2006; Boyle et al., 2009; Okenwa, Lawoko \& Jansson, 2009; Abasiubong et al., 2010; Abramsky et al., 2011; Antai \& Adaji, 2012). The household characteristics are household wealth, type of marriage, place of residence, geographic region, partner alcoholic consumption, and household decision-making. These variables are used for statistical control in the study. The variables have also been associated with intimate partner violence in previous research (Foran \& O’Leary, 2008; Mapayi et al., 2011; Bamiwuye \& Odimegwu, 2014).

Household decision-making was derived by combining women's response to participation in decisions, about their own health care, large household purchase, and visits to friends/relatives. Decision-making in which only the male partner had the final say was defined as 'male 
dominated', while others are defined as 'not male dominated'. Women's grouping into 'polygynous' or 'monogamous' unions was based on whether their male partners had at least one other wife or not. Extended family characteristics and community variables were not analysed in the study, though some of the characteristics have been associated with partner violence in previous studies (Stephenson et al., 2006; Clark et al., 2010; Antai \& Adaji, 2012). The exclusion of community characteristics was based on the fact that in the DHS datasets, community characteristics are often generated from individual characteristics, which sometimes create collinearity among the independent variables. In addition, the study analyzed more women and partner characteristics based on the assumption that the male partner is more important than other community members or features. As rightly observed by Kelly et al. (2012), if the male partner does not abuse his spouse, other family and community members are less likely to abuse her.

\section{Data Analysis}

Data were analyzed at three levels with the use of Stata (version 14). At the univariate level, respondents' socio-demographic profile, and prevalence of intimate partner violence are described using frequency distribution and percentages. At the bivariate level, unadjusted binary logit coefficients are used to describe the relationship between the independent and dependent variables. The regression coefficients showed whether the relationship was positive or negative with $95 \%$ confidence interval. At the multivariate level, odds ratios of adjusted binary logistic regression are used to further examine association between the research variables. The Stata logistic command was used to fit the binary logistic regression model (StataCorp, 2015) in four nested models. Model 1 included only number of living children, while Model 2 was based on number of living children and women's individual characteristics. Model 3 was based on number of living children and household characteristics. The full model (Model 4) included all the independent variables.

\section{Ethical considerations}

Authorization to download and analyse the datasets was granted by MEASURE DHS. The respondents analyzed in the study are anonymous. The analysis performed was not linked to specific individuals, households or communities, hence findings from the study was not offensive or injurious to any individual, household or community. 


\section{Results \\ Univariate analyses}

Table 1 presents the socio-demographic profile of respondents. The majority of respondents had two or more living children. The proportion of respondents without a living child was $4.3 \%$, while less than one-tenth of respondents had only one living child. Nearly half of respondents had no formal education. Secondary education was the dominant educational level attained among educated respondents. Slightly more than a quarter, and slightly more than one-fifth of respondents were in the younger age groups of 25-29 years and 30-34 years respectively, but more than half of respondents were in the advanced reproductive age of 35-49 years. The dominant age group at first marriage was age group 15-19 years. However, slightly more than a quarter of respondents entered marital union less than fifteen years old. The majority of respondents did not witness interparental violence, but slightly less than one-tenth of respondents witnessed interparental violence. The majority of respondents believed that wifebattery was not justified, while slightly less than a quarter believed that wifebattery was justified if wife refuses to have sex with the male partner. The majority of respondents had never terminated a pregnancy, while less-than one-fifth of respondents had ever terminated a pregnancy.

Household wealth was nearly evenly distributed among respondents, though the highest proportions of respondents were in the 'richest' household wealth category. More than one-third of respondents reside in the urban areas of the country, while slightly less than two-thirds of respondents reside in the rural areas of the country. Respondents from the north-west geo-political zone of the country were dominant in the sample. Decision-making in the majority of respondents households' was male dominated, though decisionmaking in slightly more than one-third of the households was not male dominated. Slightly more than one-fifth of respondents reported that their male partner consumes alcohol, while the majority reported otherwise. The dominant type of marriage among respondents was monogamy. However, a substantial proportion of respondents are in polygynous unions.

Table 1: Socio-demographic Profile of Respondents

\begin{tabular}{|c|c|c|c|c|c|}
\hline Variable & $\begin{array}{c}\text { Number } \\
\text { of } \\
\text { Women }\end{array}$ & Percentage & Characteristic & $\begin{array}{c}\text { Number } \\
\text { of } \\
\text { Women }\end{array}$ & Percentage \\
\hline \multicolumn{2}{|c|}{ Number of living children } & \multicolumn{2}{|c|}{ Household wealth quintile } \\
\hline No living child & 1,044 & 4.3 & Poorest & 4,978 & 20.7 \\
\hline One living child & 1,947 & 8.1 & Poorer & 4,705 & 19.6 \\
\hline $\begin{array}{c}\text { Two or more living } \\
\text { children }\end{array}$ & 21,075 & 87.6 & Middle & 4,328 & 18.0 \\
\hline \multicolumn{2}{|c|}{ Education } & Richer & 4,583 & 19.0 \\
\hline None & 10,775 & 44.8 & Richest & 5,472 & 22.7 \\
\hline Primary & 5,250 & 21.8 & Place of residence & 37.7 \\
\hline Secondary & 5,871 & 24.4 & Urban & 9,083 & 3 \\
\hline
\end{tabular}




\begin{tabular}{|c|c|c|c|c|c|}
\hline Higher & 2,170 & 9.0 & Rural & 14,983 & 62.3 \\
\hline \multicolumn{3}{|c|}{ Current age (years) } & \multicolumn{3}{|c|}{ Geographic region } \\
\hline $25-29$ & 6,188 & 25.7 & North-central & 3,389 & 14.1 \\
\hline $30-34$ & 5,362 & 22.3 & North-east & 3,425 & 14.2 \\
\hline $35-39$ & 4,901 & 20.4 & North-west & 7,241 & 30.1 \\
\hline $40-44$ & 3,911 & 16.2 & South-east & 2,361 & 9.8 \\
\hline $45-49$ & 3,704 & 15.4 & South-south & 3,029 & 12.6 \\
\hline \multicolumn{3}{|c|}{ Age at first marriage (years) } & South-west & 4,622 & 19.2 \\
\hline Less than 15 & 6,217 & 25.8 & \multicolumn{3}{|c|}{ Household decision-making } \\
\hline $15-19$ & 9,366 & 38.9 & Not male dominated & 8,982 & 37.3 \\
\hline $20-24$ & 5,331 & 22.2 & Male dominated & 15,084 & 62.7 \\
\hline 25 and above & 3,152 & 13.1 & \multicolumn{3}{|c|}{ Partner alcoholic consumption } \\
\hline \multicolumn{3}{|c|}{ Interparental violence } & Does not drink & 19,094 & 79.3 \\
\hline Did not witnessed & 21,766 & 90.4 & Drinks & 4,972 & 20.7 \\
\hline Witnessed & 2,300 & 9.6 & \multicolumn{3}{|c|}{ Type of marriage } \\
\hline \multicolumn{3}{|c|}{ Attitude to wife-battery } & Monogamy & 15,353 & 63.8 \\
\hline Not justified & 18,431 & 76.6 & Polygyny & 8,713 & 36.2 \\
\hline Justified & 5,635 & 23.4 & & & \\
\hline \multicolumn{3}{|c|}{ Pregnancy termination } & & & \\
\hline Ever terminated & 3,722 & 15.5 & & & \\
\hline Never terminated & 20,344 & 84.5 & & & \\
\hline Total & 24,066 & 100.0 & Total & 24,066 & 100.0 \\
\hline
\end{tabular}

Source: Based on 2008-2013 Nigeria Demographic and Health Surveys

Table 2 presents the prevalence of partner violence among respondents. Parous women compared with women who had no living child, had experienced more partner physical violence. For instance, parous women with two or more living children had higher prevalence of being ever slapped, and being ever kicked by male partners compared with women who had no living child. Likewise, women with one living child had higher prevalence of being ever pushed, and being ever punched by the male partner compared with women who had no living child. Parous women compared with women who had no living child had experienced at least one type of partner physical violence more than women who had no living child. However, women who had no living child had higher prevalence of being ever tried to strangled, being ever threatened with harm, and arm being ever twisted by male partner, compared to parous women.

Table 2: Percentage distribution of respondents by ever experienced intimate partner violence according to number of living children

\begin{tabular}{|c|c|c|c|}
\hline \multirow{2}{*}{ Types of intimate partner violence } & \multicolumn{3}{|c|}{ Number of living children } \\
\cline { 2 - 4 } & $\begin{array}{c}\text { No living } \\
\text { child }\end{array}$ & $\begin{array}{c}\text { One living } \\
\text { child }\end{array}$ & $\begin{array}{c}\text { Two or more } \\
\text { living children }\end{array}$ \\
\hline \multicolumn{2}{|c|}{ Physical violence } \\
\hline Ever pushed, shook, or threw something & 4.5 & 5.1 & 5.1 \\
\hline Ever slapped & 9.8 & 10.0 & 11.1 \\
\hline Ever punched with fist or something else & 3.2 & 3.3 & 3.2 \\
\hline Ever kicked, dragged or beaten up & 3.8 & 4.3 & 4.6 \\
\hline Ever tried to strangle, choke or burn & 1.6 & 1.1 & 0.9 \\
\hline Ever threatened with knife, gun, etc & 1.6 & 1.1 & 1.1 \\
\hline Ever twisted arm or pulled hair & 3.4 & 2.8 & 3.1 \\
\hline
\end{tabular}




\begin{tabular}{|c|c|c|c|}
\hline At least one physical violence & 10.5 & 11.6 & 12.8 \\
\hline \multicolumn{3}{|c|}{ Sexual violence } \\
\hline Ever physically forced to have sex & 2.9 & 3.3 & 3.2 \\
\hline Ever forced to perform other sexual acts & 1.9 & 1.6 & 1.7 \\
\hline At least one type of sexual violence & 3.1 & 3.7 & 3.6 \\
\hline \multicolumn{3}{|c|}{ Emotional violence } \\
\hline Ever humiliated in presence of others & 10.0 & 9.7 & 11.5 \\
\hline Ever threatened to hurt or harm & 4.9 & 5.7 & 5.3 \\
\hline Ever insulted or made feel bad & 12.7 & 11.8 & 14.7 \\
\hline At least one emotional violence & 16.7 & 15.3 & 19.4 \\
\hline At least one partner violence & 20.9 & 20.8 & 24.6 \\
\hline
\end{tabular}

Source: Based on 2008-2013 Nigeria Demographic and Health Surveys

Parous women compared with women who had no living child had higher prevalence of being ever forced to have sex when not wanted, but women who had no living child had higher prevalence of being ever forced to have other sexual acts by male partner compared with parous women. Parous women had higher prevalence of experiencing at least one type of partner sexual violence compared with women who had no living child. Women who had two or more living children had higher prevalence of all types of partner emotional violence compared with women who had no living child. However, women without a living child had higher prevalence of being ever insulted by their male partners, as well as higher prevalence of experiencing at least one type of partner emotional violence compared with women who had one living child. Overall, women with two or more living children had higher prevalence of experiencing at least one type of spousal violence compared with other women.

\section{Bivariate analyses}

Table 3 presents the bivariate relationships between the dependent and independent variables. Number of living children had mixed relationship with partner violence. The relationship was negative when women had one living child, but significantly positive when women had two or more living children. Women's education also had mixed relationship with number of living children. The relationship was significantly positive at primary and secondary educational levels, but negative at higher educational level. Maternal age and number of living children are negatively related, but the relationship was significant only when maternal age reaches age $45-49$ years. Age at first marriage and partner violence had mixed relationship. The relationship was positive at age groups $15-24$ years, but negative at age 25 years or older. Interparental violence and partner violence are significantly positively associated. Likewise, attitude to wife-battery and partner violence are significantly positively associated. Pregnancy termination and partner violence are significantly negatively associated. Household wealth and partner violence are positively associated, but the association was without 
statistical significance when household wealth attains the 'richest' category. Place of residence and partner violence are positively associated. Except in the south-east zone of Nigeria, geographic region and partner violence are negatively associated. Household decision-making was negatively associated with partner violence. Partner alcoholic consumption and type of marriage are positively associated with partner violence.

Table 3: Unadjusted regression coefficients showing bivariate relationships between number of living children and independent variables

\begin{tabular}{|c|c|c|c|c|c|c|c|}
\hline Variable & Coeff. & $\mathrm{p}>|\mathrm{t}|$ & $\begin{array}{c}95 \% \\
\text { CI }\end{array}$ & Characteristic & Coeff. & $\mathrm{p}>|\mathrm{t}|$ & $\begin{array}{c}95 \% \\
\mathrm{CI}\end{array}$ \\
\hline \multicolumn{4}{|c|}{ Number of living children } & \multicolumn{4}{|c|}{ Household wealth } \\
\hline $\begin{array}{l}\text { No living } \\
\text { child }^{\text {ref }}\end{array}$ & - & - & - & Poorest ${ }^{\text {ref }}$ & - & - & - \\
\hline $\begin{array}{c}\text { One living } \\
\text { child }\end{array}$ & -0.010 & 0.929 & $\begin{array}{c}-0.222 \\
0.203 \\
\end{array}$ & Poorer & 0.316 & $<0.001$ & $\begin{array}{l}0.174 \\
0.457\end{array}$ \\
\hline $\begin{array}{c}\text { Two or more } \\
\text { living } \\
\text { children }\end{array}$ & 0.206 & 0.027 & $\begin{array}{l}0.024 \\
0.388\end{array}$ & Middle & 0.467 & $<0.001$ & $\begin{array}{l}0.307 \\
0.627\end{array}$ \\
\hline \multicolumn{4}{|c|}{ Education } & Richer & 0.314 & $<0.001$ & $\begin{array}{l}0.151 \\
0.476\end{array}$ \\
\hline None ${ }^{\text {ref }}$ & - & - & - & Richest & 0.132 & 0.125 & $\begin{array}{c}-0.036 \\
0.302\end{array}$ \\
\hline Primary & 0.530 & $<0.001$ & $\begin{array}{l}0.420 \\
0.640\end{array}$ & \multicolumn{4}{|c|}{ Place of residence } \\
\hline Secondary & 0.435 & $<0.001$ & $\begin{array}{l}0.318 \\
0.552\end{array}$ & Urban $^{\text {ref }}$ & - & - & - \\
\hline Higher & -0.131 & 0.156 & $\begin{array}{l}-0.311 \\
0.050\end{array}$ & Rural & 0.099 & 0.126 & $\begin{array}{l}-0.028 \\
0.228\end{array}$ \\
\hline \multicolumn{4}{|c|}{ Age (years) } & \multicolumn{4}{|c|}{ Geographic region } \\
\hline $25-29^{\text {ref }}$ & - & - & - & North-central ${ }^{\text {ref }}$ & - & - & - \\
\hline $30-34$ & -0.058 & 0.254 & $\begin{array}{c}-0.158 \\
0.042\end{array}$ & North-east & -0.022 & 0.833 & $\begin{array}{r}-0.227 \\
0.183\end{array}$ \\
\hline $35-39$ & -0.052 & 0.356 & $\begin{array}{c}-0.163 \\
0.058 \\
\end{array}$ & North-west & -0.768 & $<0.001$ & $\begin{array}{l}-0.985 \\
-0.551 \\
\end{array}$ \\
\hline $40-44$ & -0.107 & 0.080 & $\begin{array}{c}-0.227 \\
0.013\end{array}$ & South-east & 0.053 & 0.615 & $\begin{array}{c}-0.154 \\
0.261\end{array}$ \\
\hline $45-49$ & -0.253 & $<0.001$ & $\begin{array}{l}-0.378 \\
-0.129 \\
\end{array}$ & South-south & -0.002 & 0.981 & $\begin{array}{c}-0.183 \\
0.179 \\
\end{array}$ \\
\hline \multicolumn{4}{|c|}{ Age at first marriage (years) } & South-west & -0.689 & $<0.001$ & $\begin{array}{c}-0.861 \\
0.517 \\
\end{array}$ \\
\hline Less than 15 & - & - & - & \multicolumn{4}{|c|}{ Household decision-making } \\
\hline $15-19$ & 0.158 & 0.002 & $\begin{array}{l}0.057 \\
0.260\end{array}$ & $\begin{array}{c}\text { Not male } \\
\text { dominated }^{\text {ref }}\end{array}$ & - & - & - \\
\hline $20-24$ & 0.323 & $<0.001$ & $\begin{array}{l}0.206 \\
0.440\end{array}$ & Male dominated & -0.115 & 0.018 & $\begin{array}{l}-0.210 \\
-0.020 \\
\end{array}$ \\
\hline 25 and above & -0.101 & 0.167 & $\begin{array}{c}-0.245 \\
0.043 \\
\end{array}$ & \multicolumn{4}{|c|}{ Partner alcoholic consumption } \\
\hline \multicolumn{4}{|c|}{ Interparental violence } & Does not drink ${ }^{\text {ref }}$ & - & - & - \\
\hline $\begin{array}{c}\text { Not } \\
\text { witnessed }^{\text {ref }}\end{array}$ & - & - & - & Drinks & 1.129 & $<0.001$ & $\begin{array}{l}1.026 \\
1.231 \\
\end{array}$ \\
\hline Witnessed & 1.167 & $<0.001$ & $\begin{array}{l}1.057 \\
1.277\end{array}$ & \multicolumn{4}{|c|}{ Type of marriage } \\
\hline \multicolumn{4}{|c|}{ Attitude to wife-battery } & Monogamy ${ }^{\text {ref }}$ & - & - & - \\
\hline
\end{tabular}




\begin{tabular}{|c|c|c|c|c|c|c|c|}
\hline$\underset{\text { ref }}{\text { Not justified }}$ & - & - & - & Polygyny & 0.071 & 0.120 & $\begin{array}{c}-0.018 \\
0.159\end{array}$ \\
\hline Justified & 0.450 & $<0.001$ & $\begin{array}{l}0.347 \\
0.553\end{array}$ & & & & \\
\hline \multicolumn{8}{|c|}{ Pregnancy termination } \\
\hline $\begin{array}{c}\text { Ever } \\
\text { terminated }\end{array}$ & - & - & - & & & & \\
\hline $\begin{array}{c}\text { Never } \\
\text { terminated }\end{array}$ & -0.488 & $<0.001$ & $\begin{array}{l}-0.586 \\
-0.391 \\
\end{array}$ & & & & \\
\hline
\end{tabular}

Note: ref (reference category)

\section{Multivariate analyses}

Table 4 presents the multivariate results. In Model 1 and in the absence of other covariates of partner violence, women who had two or more living children were $22.9 \%$ more likely to experience partner violence compared with women who had no living child (OR=1.229; CI: 1.0231.474). With the inclusion of women's individual characteristics in Model 2, the odds of partner violence was $15.5 \%$ higher among women who had two or more living children compared with women who had no living child (OR=1.155; CI: 0.954-1.397), but this was without statistical significance. In the model, the likelihood of partner violence was $55.4 \%$ higher among women who attained primary education (OR=1.554; CI: 1.385-1.743), and 48.3\% higher among women who attained secondary education $(\mathrm{OR}=1.483$ : CI: 1.304-1.687) compared with uneducated women. Women aged 45-49 years were $18.8 \%$ less likely to experience partner violence compared with women aged 25-29 years (OR=0.812: CI: 0.712-0.926). The odds of experiencing partner violence was higher among women who married as young adults compared with women who married at other age at first marriage categories. Women who witnessed interparental violence were nearly three times more likely to experience partner violence compared with women who do not witnessed interparental violence (OR=2.859; CI: 2.5573.195). The odds of partner violence were $67.1 \%$ higher among women who justified wife-battery compared with women who did not justify wife-battery $(\mathrm{OR}=1.671 ; \mathrm{CI}$ : 1.503-1.858). Women who had never terminated a pregnancy were $36.6 \%$ less likely to experience partner violence compared with women who had terminated a pregnancy (OR=0.634; CI: 0.574-0.701).

Table 4: Odds ratios of binary logistic regression showing effects of number of living children and other factors on partner violence

\begin{tabular}{|c|c|c|c|c|c|c|c|c|}
\hline \multirow[b]{2}{*}{ Variable } & \multicolumn{2}{|c|}{ Model 1} & \multicolumn{2}{|c|}{ Model 2} & \multicolumn{2}{|c|}{ Model 3} & \multicolumn{2}{|c|}{ Model 4} \\
\hline & $\begin{array}{l}\text { Odds } \\
\text { ratio }\end{array}$ & $\begin{array}{c}95 \% \\
\text { CI }\end{array}$ & $\begin{array}{l}\text { Odds } \\
\text { ratio }\end{array}$ & $\begin{array}{c}95 \% \\
\text { CI }\end{array}$ & $\begin{array}{l}\text { Odds } \\
\text { ratio }\end{array}$ & $\begin{array}{c}95 \% \\
\text { CI }\end{array}$ & $\begin{array}{l}\text { Odds } \\
\text { ratio }\end{array}$ & $\begin{array}{c}95 \% \\
\text { CI }\end{array}$ \\
\hline \multicolumn{9}{|c|}{ Number of living children } \\
\hline $\begin{array}{l}\text { No living } \\
\text { child } \text { ref }^{-}\end{array}$ & 1.000 & - & 1.000 & - & 1.000 & - & 1.000 & - \\
\hline $\begin{array}{c}\text { One living } \\
\text { child }\end{array}$ & 0.990 & $\begin{array}{l}0.801- \\
1.205\end{array}$ & 0.924 & $\begin{array}{l}0.742- \\
1.151\end{array}$ & 1.026 & $\begin{array}{l}0.826- \\
1.275\end{array}$ & 0.963 & $\begin{array}{l}0.771- \\
1.203\end{array}$ \\
\hline
\end{tabular}




\begin{tabular}{|c|c|c|c|c|c|c|c|c|}
\hline $\begin{array}{l}\text { Two or } \\
\text { more living } \\
\text { children }\end{array}$ & $1.229 * *$ & $\begin{array}{l}1.023- \\
1.474\end{array}$ & 1.155 & $\begin{array}{l}0.954- \\
1.397\end{array}$ & $1.277^{* *}$ & $\begin{array}{l}1.061- \\
1.537\end{array}$ & $1.205^{* *}$ & $\begin{array}{c}0.993- \\
1.461\end{array}$ \\
\hline \multicolumn{9}{|c|}{ Education } \\
\hline None ${ }^{\text {ref }}$ & & & 1.000 & - & & & 1.000 & - \\
\hline Primary & & & $1.554^{*}$ & $\begin{array}{l}1.385- \\
1.743\end{array}$ & & & $1.356^{*}$ & $\begin{array}{l}1.200- \\
1.534\end{array}$ \\
\hline Secondary & & & $1.483^{*}$ & $\begin{array}{l}1.304- \\
1.687\end{array}$ & & & $1.410^{*}$ & $\begin{array}{l}1.222- \\
1.626\end{array}$ \\
\hline Higher & & & 0.937 & $\begin{array}{c}0.766- \\
1.148\end{array}$ & & & 0.966 & $\begin{array}{c}0.777- \\
1.201\end{array}$ \\
\hline \multicolumn{9}{|c|}{ Age (years) } \\
\hline $25-29^{\text {ref }}$ & & & 1.000 & - & & & 1.000 & - \\
\hline $30-34$ & & & 0.943 & $\begin{array}{l}0.850- \\
1.846\end{array}$ & & & 0.937 & $\begin{array}{c}0.839- \\
1.047\end{array}$ \\
\hline 35-39 & & & 0.926 & $\begin{array}{l}0.826- \\
1.039\end{array}$ & & & 0.906 & $\begin{array}{c}0.802- \\
1.023\end{array}$ \\
\hline $40-44$ & & & 0.888 & $\begin{array}{c}0.782- \\
1.008\end{array}$ & & & $0.865^{* *}$ & $\begin{array}{c}0.756- \\
0.990\end{array}$ \\
\hline $45-49$ & & & $0.812^{* *}$ & $\begin{array}{l}0.712- \\
0.926\end{array}$ & & & $0.781 *$ & $\begin{array}{c}0.681- \\
0.897\end{array}$ \\
\hline \multicolumn{9}{|c|}{ Age at first marriage (years) } \\
\hline $\begin{array}{c}\text { Less than } \\
15^{\text {ref }}\end{array}$ & & & 1.000 & - & & & 1.000 & - \\
\hline $15-19$ & & & 1.082 & $\begin{array}{c}0.975- \\
0.199\end{array}$ & & & 1.029 & $\begin{array}{c}0.926- \\
1.143\end{array}$ \\
\hline $20-24$ & & & $1.212^{* *}$ & $\begin{array}{l}1.068- \\
1.375\end{array}$ & & & $1.175^{* *}$ & $\begin{array}{l}1.036- \\
1.333\end{array}$ \\
\hline $\begin{array}{l}25 \text { and } \\
\text { above }\end{array}$ & & & 0.884 & $\begin{array}{c}0.752- \\
1.040\end{array}$ & & & $0.845^{* *}$ & $\begin{array}{c}0.717- \\
0.997\end{array}$ \\
\hline \multicolumn{9}{|c|}{ Interparental violence } \\
\hline $\begin{array}{c}\text { Not } \\
\text { witnessed } \\
\text { ref }\end{array}$ & & & 1.000 & - & & & 1.000 & - \\
\hline Witnessed & & & $2.859 *$ & $\begin{array}{l}2.557- \\
3.195\end{array}$ & & & 2.273 & $\begin{array}{c}2.014- \\
2.564\end{array}$ \\
\hline \multicolumn{9}{|c|}{ Attitude to wife-battery } \\
\hline $\begin{array}{c}\text { Not } \\
\text { justified }\end{array}$ & & & 1.000 & - & & & 1.000 & - \\
\hline Justified & & & $1.671^{*}$ & $\begin{array}{l}1.503- \\
1.858\end{array}$ & & & $1.565^{*}$ & $\begin{array}{c}1.403- \\
1.747\end{array}$ \\
\hline \multicolumn{9}{|c|}{ Pregnancy termination } \\
\hline $\begin{array}{c}\text { Ever } \\
\text { terminated } \\
\text { ref }\end{array}$ & & & 1.000 & - & & & 1.000 & - \\
\hline $\begin{array}{c}\text { Never } \\
\text { terminated }\end{array}$ & & & $0.634 *$ & $\begin{array}{l}0.574- \\
0.701\end{array}$ & & & $0.667 *$ & $\begin{array}{c}0.599- \\
0.742\end{array}$ \\
\hline
\end{tabular}

Notes: ref (reference category), ${ }^{*} \mathrm{p}<0.001 .{ }^{* *} \mathrm{p}<0.05$

In Model 3, women who had two or more living children were $27.7 \%$ more likely to experience partner violence compared with women who had no living child (OR=1,277; CI: 1.061-1.537). With the exclusion of richest household wealth category, the odds of experiencing partner violence were 
significantly higher among women as household wealth improves. The likelihood of experiencing partner violence was $23.8 \%$ higher among women in north-east zone of Nigeria compared with women in the reference category (OR=1.238; CI: 1.017-1.508). The odds were lower in all other zones of the country. Women whose male partners drinks alcohol were more than three times likely to experience partner violence compared with women whose male partners do not drink alcohol (OR=3.080; CI: 2.776-3.412). Likewise, polygynous women were $15.9 \%$ more likely to experience partner violence compared with monogamous women (OR=1.159; CI: 1.062-1.265).

In the full model, and with the inclusion of all independent variables in the model, there was little change in the pattern of association between the variables, compared with pattern observed in previous models. Number of living children remained significantly associated with the odds of partner violence. Women with two or more living children were $20.5 \%$ more likely to experience partner violence compared with women who had no living child (OR=1.205; CI: 0.993-1.461). In the model, the individual characteristics, namely, women's education, maternal age, age at first marriage, interparental violence, attitude to wife-battery, and pregnancy termination remained significantly associated with the likelihood of experiencing partner violence. Likewise, household characteristics, namely, household wealth, geographic region, partner alcoholic consumption, and type of marriage remained significantly associated with the likelihood of experiencing partner violence. Place of residence and household decision did not reveal significant effects on the odds of experiencing partner violence in the models.

Table 4 continued: Odds ratios of binary logistic regression showing effects of number of living children and other factors on partner violence

\begin{tabular}{|c|c|c|c|c|c|c|c|c|}
\hline \multirow[b]{2}{*}{ Variable } & \multicolumn{2}{|c|}{ Model 1} & \multicolumn{2}{|c|}{ Model 2} & \multicolumn{2}{|c|}{ Model 3} & \multicolumn{2}{|c|}{ Model 4} \\
\hline & $\begin{array}{l}\text { Odds } \\
\text { ratio }\end{array}$ & $\begin{array}{c}95 \% \\
\text { CI }\end{array}$ & $\begin{array}{l}\text { Odds } \\
\text { ratio }\end{array}$ & $\begin{array}{c}95 \% \\
\text { CI } \\
\end{array}$ & Odds ratio & $95 \% \mathrm{CI}$ & Odds ratio & $95 \%$ CI \\
\hline \multicolumn{9}{|c|}{ Household wealth } \\
\hline Poorest ${ }^{\text {ref }}$ & & & & & 1.000 & - & 1.000 & - \\
\hline Poorer & & & & & $1.346^{*}$ & $\begin{array}{c}1.170- \\
1.549\end{array}$ & $1.266^{* *}$ & $\begin{array}{c}1.098- \\
1.459\end{array}$ \\
\hline Middle & & & & & $1.435^{*}$ & $\begin{array}{c}1.213- \\
1.697 \\
\end{array}$ & $1.307^{* *}$ & $\begin{array}{c}1.108- \\
1.543\end{array}$ \\
\hline Richer & & & & & $1.308^{* *}$ & $\begin{array}{c}1.086- \\
1.575\end{array}$ & 1.183 & $\begin{array}{c}0.979- \\
1.429\end{array}$ \\
\hline Richest & & & & & 1.221 & $\begin{array}{c}0.972- \\
1.534\end{array}$ & 1.174 & $\begin{array}{c}0.934- \\
1.476\end{array}$ \\
\hline \multicolumn{9}{|c|}{ Place of residence } \\
\hline Urban ${ }^{\text {ref }}$ & & & & & 1.000 & - & 1.000 & - \\
\hline Rural & & & & & 1.072 & $\begin{array}{c}0.929- \\
1.237 \\
\end{array}$ & 1.054 & $\begin{array}{c}0.915- \\
1.214 \\
\end{array}$ \\
\hline \multicolumn{9}{|c|}{ Geographic region } \\
\hline $\begin{array}{c}\text { North-central } \\
\text { ref }\end{array}$ & & & & & 1.000 & - & 1.000 & - \\
\hline
\end{tabular}




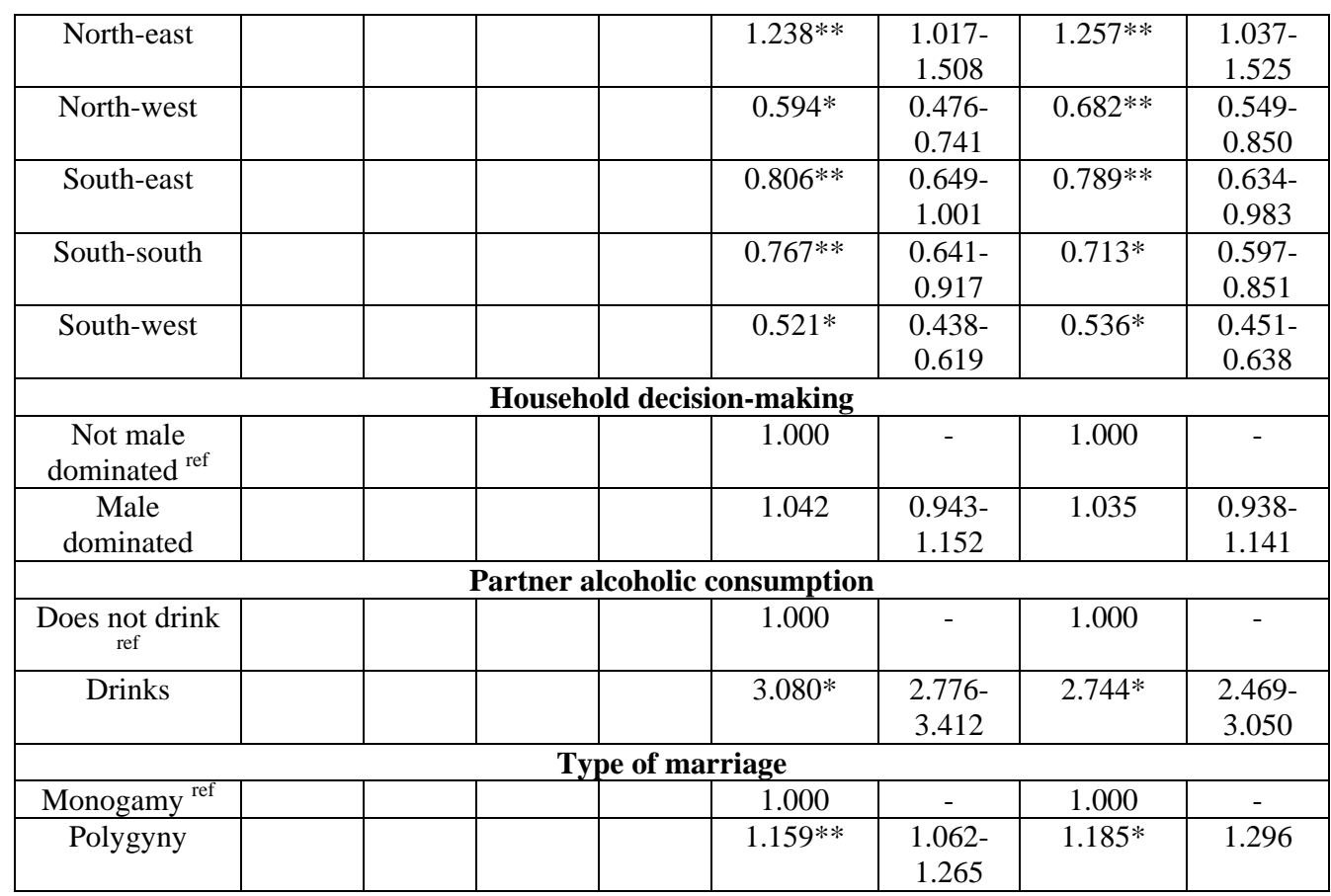

Notes: ref (reference category), ${ }^{*} \mathrm{p}<0.001{ }^{* *} \mathrm{p}<0.05$

\section{Discussion}

This study examined the relationship between number of living children and intimate partner violence in Nigeria. It improves upon previous studies that linked not having a living child and partner violence among only infertile women (Ardabily et al., 2011; Adulogu et al., 2015; Iliyasu et al., 2016; Ozgoli et al., 2016; Yildizha et al., 2016) by assessing the risks of partner violence among women with living children and women without a living child. This gives strength to the analyses. The study also draws strength from the quality of data analyzed. The analyzed data are nationally representative and presents a true picture of the links between number of living children and partner violence in Nigeria. Virtually all the independent variables analyzed in the study reveals significant association with partner violence in line with relationships observed in previous studies (Stephenson et al., 2006; Boyle et al., 2009; Okenwa et al., 2009; Abasiubong et al., 2010; Abramsky et al., 2011; Antai \& Adaji, 2012; Foran \& O’Leary, 2008; Mapayi et al., 2011).

The study revealed that inability to have a living child did not increase women's risk of experiencing partner violence. This finding is not consistent with the 2013 NDHS report that women who had no living child experienced more partner physical/sexual violence (NPC \& ICF International, 2014). The inconsistency was however, permissible on the basis that the 2013 NDHS result was based on all women, but some women 
are excluded from the present study. However, the finding was consistent with three previous studies. In the first study (McCloskey et al., 2005), women with four or more children and women without a child both had elevated risk of partner violence. In the second study (Koenig et al., 2006), it was reported that women who had no living child had lower likelihood of partner violence. In the third study (Nwaoma et al., 2012), it was found that being childless was not a predictor of partner violence. This study may have found lower risk of partner violence among women who had no living child because of its focus on mainly women and partner characteristics.

Studies such as (Clark et al., 2010), have shown that extended family members may be the major perpetrators of gender-based violence against women who are involuntarily childless. In most cases, if the male partner is tolerant and protective of his spouse, extended family or community members will not be able to ridicule or abuse the woman in spite of being childless (Kelly et al., 2012). Our finding thus, suggests that Nigerian men may be tolerant and supportive of women who are yet to have a living child. This is an important behaviour change concerns that should be strongly emphasized in all marital counselling and infertility interventions in the country. It will be almost impossible for women to cope with or overcome the mental stress and societal pressure arising from demand for children without the support and cooperation of the male partner. Bearing in mind that in virtually all Nigerian communities, men have dominance over women's sexual and reproductive behaviours, infertility interventions whether medical or non-medical should target more male involvement. This could help to further reduce the incidence of intimate partner violence among women facing fertility challenges. However, such behaviour change concern should be enhanced by improving availability of assisted reproductive technologies such as fertility medication (to stimulate ovulation), in-vitro fertilization (IVF), and artificial insemination (AI) in both secondary and tertiary health care levels in the country.

The study further revealed that parous women particularly, women with two or more living children are exposed to higher risk of partner violence. This further confirms that other issues such as, economic stress and low education within the family may have more relevance in shaping incidence and prevalence of intimate partner violence than the number of living children. Previous studies have provided evidence that across the world, pregnant women are among the groups of women who suffer intimate partner violence (Devries et al., 2010; Bessa et al., 2014), indicating that desire for a child may not be the overriding reason why women face abuse within marital unions or intimate relationships. On the contrary, the number of living children may be a major reason why women remain in unions even if they experienced intimate partner violence. Most women will choose to 
remain in a violent union if the safety of their children cannot be guaranteed by quitting the union, especially if the woman depends heavily on the male partner for economic resources. Accelerating the pace of economic empowerment among women is one viable means of ensuring that women in violent unions are able to decide quitting or remaining in a violent union without compromising their sexual and reproductive health.

This study has few limitations that could be improved upon in future studies. The data analyzed, though collected at two different time-points, was cross-sectional. This did not allow attempts to infer that number of living children cause or do not cause intimate partner violence. In addition, the data analyzed relates to the fertility-partner violence situation as at the time of the survey. The changes that have taken place in the country with respect to number of living children and partner violence are not captured in the analysis. The study assumed the trust worthiness of DHS data based on the standard methodology adopted in collecting the data, but in reality, data analyzed are based on self report. It is not impossible that some of the women may not have reported their exact experience of partner violence, which may have reduced the extent of partner violence among the respondents. Finally, future studies may adopt mixed method approach to unravel more reasons why partner violence was higher among parous women. Qualitative data was not collected for the present study because the objective was to assess extent of risks among women who had living children and those who had no living child.

\section{Conclusion}

Based on Nigeria DHS, this study provided empirical evidence that having living children increase women's risk of intimate partner violence. It is important that women experiencing any type of intimate partner violence seek psycho-social counselling to reduce the incidence of intimate partner violence that may arise from childbearing. Also, expanding medical services, particularly, assisted reproductive technologies will enhance the prospect of men, women, or couples who desire children but involuntarily childless, to not only achieve their desired fertility, but also reduce the potency of a possible cause of marital discord. Adequate enforcement of legislations against women, irrespective of their fertility status will also enhance the promotion of women's sexual and reproductive health in the country, particularly in the north-east geo-political zone.

\section{Acknowledgements}

The author appreciates and thanks the National Population Commission (NPC) [Nigeria], ICF International and MEASURE DHS 
Project for making the datasets available for use, and for granting authorisation to download/analyze the data.

\section{References:}

1. Abasiubong, F., Abasiattai, A. M., Bassey, E. A., \& Ogunsemi, O. O. (2010). Demographic Risk Factors in Domestic Violence among Pregnant Women in Uyo, a Community in the Niger Delta Region, Nigeria. Health Care for Women International, 31(10), 891901, doi:10.1080/07399332.2010.486882

2. Abramsky, T., Watts, C. H., Garcia-Moreno, C., Devries, K., Kiss, L., Ellsberg, M., et al. (2011). What factors are associated with recent intimate partner violence? Findings from the WHO multi-country study on women's health and domestic violence. BMC Public Health, 11, 109, http://www.biomedcentral.com/14712458/11/109

3. Aduloju, P. O., Olagbuji, N. B., Olofinbiyi, A. B., \& Awoleke, J. O. (2015). Prevalence and predictors of intimate partner violence among women attending infertility clinic in south-western

Nigeria. European Journal of Obstetrics \& Gynaecology and Reproductive Biology, 188, 66-69, http://dx.doi.org/10.1016/j.ejogrb.2015.02.027

4. Antai, D., \& Adaji, S. (2012). Community-level influences on women's experience of intimate partner violence and terminated pregnancy in Nigeria: a multilevel analysis. $\boldsymbol{B M C}$

\section{Pregnancy and Childbirth, 12,} http://www.biomedcentral.com/1471-2393/12/128

5. Ardabily, H. E., Moghadam, Z. B., Salsali, M., Ramezanzadeh, F., \& Nedjat, S. (2011). Prevalence and risk factors for domestic violence against infertile women in an Iranian setting. International Journal of Gynaecology and Obstetrics, 112, 15-17, doi:10.1016/j.ijgo.2010.07.030

6. Bamiwuye, S. O., \& Odimegwu, C. (2014). Spousal violence in subSaharan Africa: does household poverty-wealth matter? Reproductive Health, 11, 45, http://www.reproductive-healthjournal.com/content/11/1/45

7. Bessa, M. M. M., Drezett, J., Rolim, M., \& Carlos de Abreu, L. (2014). Violence against women during pregnancy: sistematized revision. Reprodução \& Climatério, 29(2), 71-79, http://dx.doi.org/10.1016/j.recli.2014.09.001,

8. Boerma, J. T., \& Mgalla, Z. (1999). Women and Infertility in SubSaharan Africa.

Reproductive Health Matters, 7(13), 183-188 
9. Boyle, M. H., Georgiades, K., Cullen, J., \& Racine, Y. (2009). Community influences on intimate partner violence in India: Women's education, attitudes towards mistreatment and standards of living. Social Science \& Medicine, 69, 691-697, doi:10.1016/j.socscimed.2009.06.039

10. Caldwell, J. C, \& Caldwell, P. (1987). The Cultural Context of High Fertility in sub-Saharan

Africa. Population and Development

Review, 13(3), 409-437

11. Clark, C. J., Silverman, J. G., Shahrouri. M., Everson-Rose, S., \& Groce, N. (2010). The role of the extended family in women's risk of intimate partner violence in Jordan. Social Science

Medicine, 70, 144-151, doi:10.1016/j.socscimed.2009.09.024

12. Cleland, J. G., Ndugwa, R. P., \& Zulu, L. M. (2011). Family planning in sub-Saharan

Africa: progress or stagnation? Bulletin of World Health Organization, 89, 137-143, doi:10.2471/BLT.10.077925

13. Devries, K. M, Kishor, S., Johnson, H., Stöckl, H., Bacchus L. J., Garcia-Moreno, C., et al. (2010). Intimate partner violence during pregnancy: analysis of prevalence data from 19

Reproductive Health Matters, 18(36), 158-170

14. Devries, K. M., Watts, C., Yoshihama, M., Kiss, L., Schraiber, L. B., Deyessa, N., et al. (2011). Violence against women is strongly associated with suicide attempts: Evidence from the WHO multi-country study on women's health and domestic violence against women. Science \& Medicine, 73, 79-86, doi:10.1016/j.socscimed.2011.05.006

15. Ezeh, A. C., Mberu, B. U., \& Emina, J. O. (2009). Stall in fertility decline in Eastern African countries: regional analysis of patterns, determinants and implications. Philosophical Transactions of the Royal Society B, 364, 2991-3007, doi:10.1098/rstb.2009.0166

16. Fapohunda, E. R., \& Todaro, M. P. (1988). Family Structure, Implicit Contracts, and the Demand for Children in Southern Nigeria. Population and Development Review, 14(4), $571-594$

17. Federal Ministry of Health (2004). Revised National Health Policy. Abuja, Nigeria: FMoH.

Retrieved from http://cheld.org/wp-content/uploads/2012/04/Nigeria-RevisedNational-Health-Policy- 2004.pdf

18. Federal Ministry of Health (2010). National Family Planning/Reproductive Health Service Protocols (Revised edition). Abuja, Nigeria: FMoH 
19. Federal Ministry of Women's Affairs and Social Development. (2006). National Gender Policy.

Abuja, Nigeria: FMWA $\&$ SD

20. Fledderjohann, J. J. (2012). 'Zero is not good for me': implications of infertility in Ghana.Human Reproduction, 27(5), 1383-1390, doi:10.1093/humrep/des035

21. Foran, H. M., \& O'Leary, K. D. (2008). Alcohol and intimate partner violence: A metaanalytic review. Clinical Psychology Review, 28, 1222-1234, doi:10.1016/j.cpr.2008.05.001

22. Head, S. K., Zweimueller, S., Marchena, C., \& Hoel, E. (2014). Women's Lives and Challenges: Equality and Empowerment since 2000. Rockville, Maryland, USA: ICF International

23. Hammarberg, K., \& Kirkman, M. (2013). Infertility in resourceconstrained settings: moving towards amelioration. Reproductive Biomedicine Online. 26, 189-195, http://dx.doi.org/10.1016/j.rbmo.2012.11.009

24. Ibisomi, L, \& Mudege, N. N. (2014). Childlessness in Nigeria: perceptions and acceptability.Culture, Health and Sexuality, 16(1), 61-75, doi:10.1080/13691058.2013.839828

25. ICF International (2012). Survey Organization Manual for Demographic and Health Surveys. MEASURE DHS. Calverton, Maryland, USA: ICF International. Retrieved from http://dhsprogram.com/pubs/pdf/DHSM10/DHS6_Survey_Or g_Manual_7Dec2012__ DHSM10.pdf

26. Iliyasu, Z., Galadanci, H. S., Abubakar, S., Auwal, M. S, Odoh, C., Salihu, H. M., et al. (2016). Phenotypes of intimate partner violence among women experiencing infertility in Kano, Northwest Nigeria. International Journal of Gynaecology and Obstetrics, 133, 32-36, http://dx.doi.org/10.1016/j.ijgo.2015.08.010

27. Inhorn, M. C. (2009). Right to assisted reproductive technology: Overcoming infertility in low -resource countries. International Journal of Gynecology and Obstetrics, 106, 172-174, doi:10.1016/j.ijgo.2009.03.034

28. Inhorn, M. C., \& Patrizio, P. (2015). Infertility around the globe: new thinking on gender, reproductive technologies and global movements in the 21st century. Human Reproduction Update, 0(0), 1-16, doi:10.1093/humupd/dmv016

29. Jina, R., \& Thomas, L. S. (2013). Health consequences of sexual violence against women. Best Practice \& Research Clinical Obstetrics and Gynaecology, 27, 15-26, http://dx.doi.org/10.1016/j.bpobgyn.2012.08.012 
30. Kalmijn, M., \& Poortman, A. R. (2006). His or Her Divorce? The Gendered Nature of Divorce and its Determinants. Sociological Review, 22(2), 201-214, doi:10.1093/esr/jci052

31. Kelly, J. Kabanga, J., Cragin, W., Alcayna-Stevens, L., Haider, S., \& Vanrooyen, M. J. (2012). 'If your husband doesn't humiliate you, other people won't': Gendered attitudes towards sexual violence in eastern Democratic Republic of Congo. Global Public Health, 7(3), 285-298, doi:10.1080/17441692.2011.585344

32. Koenig, M. A., Stephenson, R., Ahmed, S., Jejeebhoy, S. J., \& Campbell, J. (2006). Individual and Contextual Determinants of Domestic Violence in North India. American Journal of Public Health, 96, 132-138, doi:10.2105/AJPH.2004.050872

33. Larsen, U. (2005). Research on infertility: which definition should we use? Fertility and Sterility, 83(4), 846-852, doi:10.1016/j.fertnstert.2004.11.033

34. Larsen, U., Hollos, M., Obono, O., \& Whitehouse, B. (2010). Suffering Infertility: The Impact of Infertility on Women's Life Experiences in Two Nigerian Communities. Journal of Biosocial Science, 42, 787-814, doi:10.1017/S0021932010000271

35. Makinde, O. A., Olaleye, O., Makinde, O. O., Huntley, S. S., \& Brown, B. (2015). Baby Factories in Nigeria: Starting the Discussion Toward a National Prevention Policy. Trauma,

Violence \& Abuse, 1-8, doi:10.1177/1524838015591588

36. Mapayi, B., Makanjuola, R., Fatusi, A. O., \& Afolabi, O. T. (2011). Socio-Demographic Factors Associated With Intimate Partner Violence In Ile-Ife, Nigeria. Gender \& Behaviour, 9(1), 3466-3478

37. McCloskey, L. A., Williams, C., \& Larsen, U. (2005). Gender Inequality and Intimate Partner Violence among Women in Moshi, Tanzania. International Family Planning Perspectives, 31(3), 124-130

38. National Population Commission (2004). National Policy on Population for Sustainable Development. Abuja, Nigeria: NPC

39. National Population Commission (NPC) [Nigeria] \& ICF Macro. (2009). Nigeria Demographic and Health Survey 2008. Abuja, Nigeria: National Population Commission and ICF Macro. Retrieved from http://www.dhsprogram.com/pubs/pdf/FR222/FR222.pdf

40. National Population Commission (NPC) [Nigeria] \& ICF International. (2014). Nigeria Demographic and Health Survey 2013. Abuja, Nigeria, and Rockville, Maryland, USA: 
NPC and ICF International. Retrieved from http://www.dhsprogram.com/pubs/pdf/FR293/FR293.pdf

41. Ofovwe, C. E., \& Agbontaen-Eghafona, K. A. (2009). Infertility in Nigeria: A Risk Factor for Gender Based Violence. Gender \& Behaviour, 7(2), 2326-2344

42. Okenwa, L. E., Lawoko, S., \& Jansson, B. (2009). Exposure to Intimate Partner Violence amongst Women of Reproductive age in Lagos, Nigeria: Prevalence and Predictors. Journal of Family Violence, 24, 517-530, doi:10.1007/S10896-0099250-7

43. Ola, T. M. (2012). Assisted Reproductive Technology in Nigeria: Flawed or Favored? International Journal of Social Science and Humanity, 2(4), 331-334

44. Omokhodion, F. O., \& Uchendu, O. C. (2010). Perception and practice of child labour among parents of school-aged children in Ibadan, southwest Nigeria. Child: care, health and development, 36(3), 304-308, doi:10.1111/j.1365-2214.2009.00988.x

45. Omosun, A. O., \& Kofoworola, O. (2011). Knowledge, attitude and practice towards child adoption amongst women attending infertility clinics in Lagos State, Nigeria. African Journal of Primary Health Care and Family Medicine, 3(1), doi:10.4102/phcfm.v3i1.259

46. Onyemelukwe, C. (2016). Legislating on Violence Against Women: A Critical Analysis of Nigeria's Recent Violence Against Persons (Prohibition) Act, 2015. DePaul Journal of Women, Gender and the Law, 5(2), Retrieved from http://via.library.depaul.edu/jwgl/vol5/iss2/3 : are health and development Child: care, health and development

47. Onyishi, E. I., Sorokowski, P., Sorokowska, A., \& Pipitone, R. N. (2012). Children and marital satisfaction in a non-Western sample: having more children increases marital satisfaction among the Igbo people of Nigeria. Evolution and Human Behavior, 33, 771-774, http://dx.doi.org/10.1016/j.evolhumbehav.2012.06.005

48. Ozgoli, G., Sheikhan, Z., Zahiroddin, A., Nasiri, M., Amiri, S., \& Badr, F. K. (2016). Evaluation of the Prevalence and Contributing Factors of Psychological Intimate Partner Violence in Infertile Women. Journal of Midwifery \& Reproductive Health, 4(1), 571-581, 49. Pereira, A. R., Vieira, D. N., \& Magalhães, T. (2013). Fatal intimate partner violence against women in Portugal: A forensic medical national study. Journal of Forensic and Legal Medicine, 20, 1099-1107, http://dx.doi.org/10.1016/j.jflm.2013.09.015 
50. Population Reference Bureau (2015). 2015 World Population Data Sheet with a special focus on women empowerment. Retrieved from www.prb.org

51. StataCorp (2015) Stata: Release 14. Statistical Software. College Station, TX: StataCorp LP.

52. Stephenson, R., Baschieri, A., Clements, S., Hennink, M., \& Madise, N. (2006). Contextual Influences on the Use of Health Facilities for Childbirth in Africa. American Journal of Public Health, 96, 84-93, doi:10.2105/AJPH.2004.057422

53. Sultan, S. (2010). Marital Discord: The Hidden Burden of Infertility. Pakistan Journal of Psychological Research, 25(1), 31-43

54. Uwaoma, N. C., Osita-Njoku, A., \& Madukwe, A. U. (2012). Education, Male Child and Childlessness as Predictors of Spouse Abuse among Rural and Urban Igbo-Nigerian Women. Canadian Social Science, 8(1), 70-76, doi:10.3968/j.css.1923669720120801.378

55. Van den Broeck, U., Emery, M., Wischmann, T., \& Thorn, P. (2010). Counselling in infertility: Individual, couple and group interventions. Patient Education and Counseling, $\quad 81, \quad 422-$ 428,doi:10.1016/j.pec.2010.10.009

56. World Health Organization (2012) Understanding and addressing violence against women. Retrieved from http://apps.who.int/iris/bitstream/10665/77433/1/WHO_RHR_12.35_ eng.pdf

57. World Health Organization (2013) Global and regional estimates of violence against women: prevalence and health effects of intimate partner violence and non-partner sexual violence. Geneva, Switzerland: WHO

58. Yildizhan, R., Adali, E., Kolusari, A., Kurdoglu, M., Yildizhan, B., \& Sahin, G. (2009). Domestic violence against infertile women in a Turkish setting. International Journal of Gynaecology and Obstetrics, 104, 110-112, doi:10.1016/j.ijgo.2008.10.007 